\title{
CARCASS YIELD OF BROILER CHICKENS FED BANANA (Musa paradisiaca) LEAVES FERMENTED WITH Trichoderma viride
}

\author{
J. S. Mandey, J. R. Leke, W. B. Kaunang and Y. H. S. Kowel \\ Animal Husbandry Faculty, Sam Ratulangi University, \\ Jl. Kampus Selatan, Kleak Manado 95115 - Indonesia \\ Corresponding E-mail: jetsm_fapet@yahoo.co.id
}

Received September 29, 2015; Accepted November 20, 2015

\begin{abstract}
ABSTRAK
Penelitian ini dilakukan untuk mengevaluasi pengaruh level daun pisang (Musa paradisiaca) yang difermentasi dengan Trichoderma viride dalam beberapa masa inkubasi terhadap karkas ayam pedaging. Sebanyak 180 ekor ayam broiler umur 3 minggu digunakan dalam penelitian yang didesain berdasarkan Rancangan Acak Lengkap pola Faktorial (3×4). Ayam broiler dialokasikan secara acak ke dalam tiga ransum perlakuan yang mengandung 5,10 dan $15 \%$ tepung daun pisang yang diinkubasi selama $0,5,10$ dan 15 hari. Setiap perlakuan diulang tiga kali dan setiap unit percobaan terdiri dari lima ekor ayam. Penelitian dilaksanakan selam empat minggu, dan peubah yang diukur adalah konsumsi pakan, pertambahan berat badan, efisiensi penggunaan pakan dan produksi karkas. Semua data yang diperoleh dianalisis keragamannya dan dilanjutkan dengan uji Beda Nyata Terkecil. Hasil penelitian menunjukkan bahwa perlakuan kombinasi level daun pisang dan lama inkubasi berpengaruh sangat nyata $(\mathrm{P}<0,01)$ terhadap konsumsi pakan, dengan nilai konsumsi pakan yang paling tinggi diperoleh pada perlakuan $10 \%$ daun pisang yang diinkubasi 10 hari. Selanjutnya, perlakuan kombinasi level daun pisang dan lama inkubasi berpengaruh sangat nyata $(\mathrm{P}<0,01)$ terhadap pertambahan berat badan, efisiensi penggunaan pakan dan produksi karkas, dengan nilai konsumsi pakan yang paling tinggi diperoleh pada perlakuan $10 \%$ daun pisang yang diinkubasi 10 hari. Dapat disimpulkan bahwa pakan dengan kandungan 10\% daun pisang yang diinkubasi selama 10 hari memberikan hasil yang terbaik.
\end{abstract}

Kata kunci: daun pisang, fermentasi, karkas, ayam pedaging

\begin{abstract}
The study was conducted to evaluate the effect of level of banana (Musa paradisiaca) leaves fermented with Trichoderma viride at different days on the carcass yield of broiler chickens. A hundred and eighty 3-weeks-old broiler chicks were used in this present experiment based on factorial design $(3 \times 4)$. The birds were randomly allocated into three experimental diets containing of 5,10 and $15 \%$ of banana leaves fermented within 0, 5, 10 and 15 days. Each treatment was divided into three replicates of five chicks in each. The experiment was terminated after 4 weeks or when the birds were 7-weeks-old. Feed intake, body weight gain, feed efficiency and carcass yield were measured during the study. The data were subjected to the analysis of variance test followed by least significant difference (LSD) test. Results showed that daily feed intake was significantly affected $(\mathrm{P}<0.01)$ by the dietary treatments, in which feed intake was highest in broilers fed diet containing $10 \%$ banana leaves fermented for 10 days. The daily weight gain, feed efficiency and carcass yield were significantly affected $(\mathrm{P}<0.01)$ by the treatments, in which the highest values of daily weight gain, feed efficiency, and carcass yield were observed in birds fed diet containing $10 \%$ banana leaves fermented for 10 days. It can be concluded that diet containing $10 \%$ banana leaves fermented for 10 days can be included in broiler ration without detrimental effects on the performance and carcass yield.
\end{abstract}

Keywords: banana leaves, incubation, carcass, broiler 


\section{INTRODUCTION}

It has been acknowledged that most of total farming cost in broiler production comes from feed expenses. Therefore reduced feed costs may lead to improved production efficiency and profitability of broiler production. The use of unconventional feed ingredients such as banana (Musa paradisiaca) leaves could be the alternative. This application may improve the profit margin through reducing the use of expensive conventional protein sources (Iheukwume et al., 2008). Banana is the second largest produced fruit after citrus, contributing about $16 \%$ of the world's total fruit production. Indeed, banana is cultivated over 130 countries, both in tropics and subtropics regions (Mohapatra et al., 2010; Bera et al., 2013). Banana is not a seasonal fruit and it is therefore available throughout the year. There are three most common bananas in the world, i.e., $M$. cavendishii, M. paradisiaca and M. sapientum (Mohapatra et al., 2010).

It has been reported that banana leaves were a good source of lignin. Leaf blade and leaf sheaths have a high content of pentosan, as well as cellulose (20.4 - 37.3\%) (Mohapatra et al., 2010). Moreover, protein content in leaf blade was also substantial. Hence, banana leaves could be an ideal substitute of roughage for cattle. To improve the digestibility of banana leaves, addition of protein extract has been commonly practiced in ruminants (Katangole et al., 2008). However, information about the utilization of banana leaf for broiler chickens was not available in the literature to date. Probably, the high content of cellulose in the leaf limit the utilization of such stuff in broiler ration. It is known that fermentation is a simple method to lower the fibre content of feed ingredients. Hence, the objective of this study was to evaluate the effects of banana leaves fermented with Trichoderma viride within different time on the performance and carcass yield of broiler chickens.

\section{MATERIALS AND METHODS}

\section{Sample preparation}

Banana leaves were obtained from local plantations from the area of Minahasa district, Indonesia. The leaves were washed and sun-dried to constant weight for 3-5 days. The leaves were ground, milled and then mixed with $T$. viride followed by incubation within different days, i.e.,
$0,5,10$ and 15 days, respectively. The fermented leaves were subsequently mixed with other feed ingredients before feeding to broiler chickens.

\section{Experimental Birds, Design and Management}

A total of 180 broiler chicks ( 3 weeks of age) were used in the study, which was set up based on factorial arrangement $(3 \times 4)$. The birds were randomly allocated into three experimental diets containing of 5,10 and $15 \%$ of banana leaves fermented within 0, 5, 10 and 15 days. Each treatment was divided into three replicates of five chicks in each. The experiment lasted for 4 weeks or when the birds were 7-weeks-old.

Basal diet contained 54\% yellow corn, 7.5\% rice bran, $10 \%$ coconut cake, $12 \%$ soybean cake, $16 \%$ fish meal and $0.5 \%$ top mix. The diets used in the experiment and the nutrient analysis banana leaf are presented on Table 1 and Table 2, respectively. The birds were subjected to a standard broiler management procedure. At the beginning of the experiment, initial weights of the birds were determined and subsequent body weights and feed intake were measured weekly. At the end of experiment, final body weight was measured, and bird from each pen was randomly selected, weighed and slaughtered. After slaughter, carcass (chilled) weight was determined after removal of feather, head, lungs, gastrointestinal tract, liver, kidney and abdominal fat. Carcass yield was calculated as the percentage of fasted live body weight.

\section{Statistical Analysis}

The data were subjected to the analysis of variance (ANOVA) test followed by least significant difference (LSD) test (Steel and Torrie, 1980).

\section{RESULTS AND DISCUSSION}

The results of proximate analysis of banana leaves are presented in Table 1. The crude protein value of fermented banana leaves was higher than that of reported by Mohapatra et al. (2010) and Sen et al. (2014). The protein value was also higher than that in the most of grasses in the natural grassland (Singh, 1998). The chemical compositions of banana leaves after fermentation are shown in Table 1. The data shows that crude protein in banana leaves increased, whereas crude fibre decreased after incubation with $T$. viride, as compared to the unfermented one. This finding suggested that banana leaves can be used as a 
Table 1. Nutrients of Based Diet and Banana Leaf

\begin{tabular}{lrcccc}
\hline & & \multicolumn{4}{c}{ Banana Leaf Fermented } \\
\cline { 3 - 6 } Nutrients & Based Diet & $\begin{array}{c}\text { A0 } \\
\text { (unfermented) }\end{array}$ & $\begin{array}{c}\text { A1 (5d } \\
\text { fermented) }\end{array}$ & $\begin{array}{c}\text { A2 }(10 \mathrm{~d} \\
\text { fermented) }\end{array}$ & $\begin{array}{c}\text { A3 (15d } \\
\text { fermented }\end{array}$ \\
\hline Crude Protein (\%) & 21.52 & 9.24 & 11.47 & 13.82 & 14.42 \\
Fat (\%) & 6.90 & 11.35 & 11.60 & 11.68 & 11.88 \\
Crude Fiber (\%) & 4.26 & 18.74 & 18.40 & 12.70 & 10.22 \\
Nitrogen Free Extract (\%) & - & 45.16 & 45.56 & 47.08 & 47.86 \\
Ash (\%) & - & 15.52 & 12.97 & 14.72 & 15.62 \\
Ca (\%) & 0.88 & 0.19 & 0.17 & 0.21 & 0.22 \\
P (\%) & 0.76 & 0.33 & 0.30 & 0.38 & 0.40 \\
Energy (Kcal/kg) & 3029 & 3810 & 3811 & 3900 & 3915 \\
\hline
\end{tabular}

Table 2. Composition and Nutrients of Treatments

\begin{tabular}{|c|c|c|c|c|c|c|c|}
\hline \multicolumn{2}{|c|}{ Treatments } & \multicolumn{5}{|c|}{ Nutrients of the Diets (\%) } & \multirow{2}{*}{$\begin{array}{c}\mathrm{ME} \\
(\mathrm{Kcal} / \mathrm{Kg})\end{array}$} \\
\hline A (term) & $\mathrm{B}(\%)$ & $\begin{array}{l}\text { Crude } \\
\text { Protein }\end{array}$ & Crude Fiber & Fat & $\mathrm{Ca}$ & $\mathrm{P}$ & \\
\hline \multirow{3}{*}{0} & 5 & 20.90 & 4.98 & 7.12 & 1.01 & 1.03 & 3030.86 \\
\hline & 10 & 20.29 & 5.71 & 7.34 & 0.96 & 0.97 & 3031.76 \\
\hline & 15 & 19.68 & 6.44 & 7.57 & 0.91 & 0.94 & 3032.66 \\
\hline \multirow{3}{*}{5} & 5 & 21.01 & 4.97 & 7.14 & 0.99 & 1.00 & 3030.90 \\
\hline & 10 & 20.51 & 5.68 & 7.37 & 0.94 & 0.95 & 3031.84 \\
\hline & 15 & 20.02 & 6.39 & 7.61 & 0.88 & 0.90 & 3032.78 \\
\hline \multirow{3}{*}{10} & 5 & 21.13 & 4.68 & 7.14 & 1.03 & 1.08 & 3034.46 \\
\hline & 10 & 20.75 & 5.11 & 7.37 & 0.98 & 1.02 & 3038.96 \\
\hline & 15 & 20.37 & 5.53 & 7.62 & 0.92 & 0.97 & 3043.46 \\
\hline \multirow{3}{*}{15} & 5 & 21.16 & 4.56 & 7.15 & 1.03 & 1.10 & 3035.06 \\
\hline & 10 & 20.81 & 4.86 & 7.39 & 0.98 & 1.04 & 3040.16 \\
\hline & 15 & 20.46 & 5.16 & 7.65 & 0.93 & 0.99 & 3045.26 \\
\hline
\end{tabular}

$\mathrm{A}=$ term of incubation; $\mathrm{B}=$ level of banana leaves

feedstuff in broiler diets after fermentation with $T$. viride.

The performances of broilers at the finisher phase (3-7 weeks) are presented in Table 3. The results showed that daily feed intake of broilers was affected $(\mathrm{P}<0.01)$ by the treatments, in which the feed intake was highest in broilers fed diet containing $10 \%$ banana leaves fermented for 10 days $(125.10 \mathrm{~g} /$ day $)$. The high amount of feed intake in these birds seemed to be due to the increased palatability of the banana leaves as also reported by Ukwah et al. (2014). The daily weight gain of broilers was also affected $(\mathrm{P}<0.01)$ by the treatments, in which the highest value was 
Table 3. Growth Performance of Broilers

\begin{tabular}{ccccc}
\hline \multirow{2}{*}{ Parameter } & \multirow{2}{*}{$\begin{array}{c}\text { Terms of } \\
\text { Incubation (A) }\end{array}$} & 5 & 10 & 15 \\
\cline { 3 - 5 } & 0 & $103.22 \pm 0.62^{\mathrm{f}}$ & $115.57 \pm 0.39^{\mathrm{e}}$ & $117.79 \pm 0.65^{\mathrm{d}}$ \\
& 5 & $117.65 \pm 0.29^{\mathrm{d}}$ & $117.82 \pm 0.25^{\mathrm{d}}$ & $116.86 \pm 0.22^{\mathrm{d}}$ \\
Feed intake (g/d) & 10 & $122.62 \pm 0.57^{\mathrm{b}}$ & $125.10 \pm 0.11^{\mathrm{a}}$ & $119.75 \pm 0.95^{\mathrm{c}}$ \\
& 15 & $124.06 \pm 0.56^{\mathrm{ab}}$ & $124.49 \pm 0.17^{\mathrm{ab}}$ & $123.86 \pm 0.49^{\mathrm{ab}}$ \\
Weight gain (g/d) & 0 & $43.46 \pm 0.74^{\mathrm{e}}$ & $48.50 \pm 0.32^{\mathrm{d}}$ & $47.04 \pm 0.96^{\mathrm{d}}$ \\
& 5 & $52.47 \pm 0.22^{\mathrm{b}}$ & $54.25 \pm 0.68^{\mathrm{b}}$ & $48.45 \pm 0.32^{\mathrm{d}}$ \\
& 10 & $53.27 \pm 0.48^{\mathrm{b}}$ & $58.03 \pm 0.32^{\mathrm{a}}$ & $50.24 \pm 0.85^{\mathrm{c}}$ \\
Feed efficiency & 15 & $50.44 \pm 0.51^{\mathrm{c}}$ & $46.15 \pm 0.70^{\mathrm{d}}$ & $49.42 \pm 0.89^{\mathrm{cd}}$ \\
& 0 & $0.42 \pm 0.008^{\mathrm{c}}$ & $0.42 \pm 0.002^{\mathrm{c}}$ & $0.40 \pm 0.06^{\mathrm{c}}$ \\
& 5 & $0.45 \pm 0.01^{\mathrm{ab}}$ & $0.46 \pm 0.06^{\mathrm{ab}}$ & $0.41 \pm 0.02^{\mathrm{c}}$ \\
& 10 & $0.43 \pm 0.04^{\mathrm{b}}$ & $0.46 \pm 0.02^{\mathrm{a}}$ & $0.42 \pm 0.07^{\mathrm{c}}$ \\
& 15 & $0.41 \pm 0.04^{\mathrm{c}}$ & $0.37 \pm 0.06^{\mathrm{d}}$ & $0.40 \pm 0.06^{\mathrm{c}}$ \\
Carcass (\%) & 0 & $68.42 \pm 0.14^{\mathrm{c}}$ & $66.65 \pm 0.62^{\mathrm{d}}$ & $67.95 \pm 0.39^{\mathrm{cd}}$ \\
& 5 & $73,75 \pm 0.76^{\mathrm{ab}}$ & $74.27 \pm 0.62^{\mathrm{ab}}$ & $72.58 \pm 0.44^{\mathrm{b}}$ \\
& 10 & $72.24 \pm 0.38^{\mathrm{b}}$ & $74.58 \pm 0.27^{\mathrm{a}}$ & $72.60 \pm 0.34^{\mathrm{b}}$ \\
& 15 & $65.81 \pm 0.20^{\mathrm{de}}$ & $73.03 \pm 0.38^{\mathrm{ab}}$ & $71.67 \pm 0.53^{\mathrm{c}}$
\end{tabular}

${ }^{\mathrm{a}}$ in the same parameters are the best interaction

observed in birds fed diet containing 10\% banana leaves fermented for 10 days $(58.03 \mathrm{~g} /$ day). The result was similar to that of reported by Ukwah et al. (2014) who found that feeding 10\% banana peel powder significantly increased growth performance as compared to control. In the present study, the best feed efficiency was observed in the birds fed diet containing $10 \%$ banana leaves fermented for 10 days (0.46). This present finding was in accordance with that of reported by Taiwo et al. (2005). The improved feed efficiency of birds fed $10 \%$ banana leaves fermented for 10 days may be due to the increased digestive enzymes activity resulting in better digestion and utilization of feed. Overall, the survivability was $100 \%$ for all of the treatment groups.

The carcass yield was significantly affected $(\mathrm{P}<0.01)$ by the treatments, in which the carcass yield was highest from the birds fed diet containing $10 \%$ banana leaves fermented for 10 days $(74.58 \%)$. To date, there was no information regarding the effect of banana leaves on broiler carcass. However, Ayyola et al. (2014) reported that utilization of thyme leaves in broiler diet did not have significant effect on dressed carcass percentage. It is therefore suggested that feeding diet containing $10 \%$ banana leaves fermented for 10 days will produce the best carcass yield of broilers.

\section{CONCLUSION}

Based on the present data, it can be concluded that diet containing $10 \%$ banana leaves fermented for 10 days can be included in broiler ration without detrimental effects on the performance and carcass yield.

\section{REFERENCES}

Ayyola, M., O. A. Adedeji and A. D. Oladepo. 
2014. Effect of dietary thyme leaf on broiler growth performances, carcass characteristics and cooking yield of the meat. Global J. Sci. Res. 2 (2): 47-50.

Bera, S., S. Bhattachanya, J.N. Pandey and M. Biswas. 2013. Acute and sub-chronic toxicity study of Musa paradisiaca leaf extracts in mice. J. Adv. Pharm. Edu. Res. 3(2): 90-93.

Iheukwumere, F.C., E.C. Ndubuisi, E.A. Mazi and M.U. Onyekwere. 2008. Performance, nutrients utilization and organ characteristics of broilers fed cassava leaf meal (Manihot esculenta Crantz). Pak. J. Nutr. 7: 13-17.

Katangole, C.B., F.B. Bareeba, E.N. Sabiiti and I. Ledin. 2008. Nutritional characterization of some tropical urban market crops wastes. Anim. Feed Sci. Technol. 142: 275-291.

Matekaire, T., J.F. Mupangwa and E.F. Kanyamura. 2005. The efficacy of banana plant (Musa paradisiana) as a coccidiostat in rabbits. Int. J. Appl. Res. Vet. Med. 3(4): 326-331.

Mohapatra, D., S. Mishra and N. Sutar. 2010.
Banana and its by-product utilisation: an overview. J. Sci. Indust. Res. 69: 23-329.

Sen, B., J. Singh, T. Verma and P.R. Patel. 2014. Performance of growing calves fed on banana (Musa paradisiaca) stem. Bioscan. 9(1): 121-123.

Singh, J. 1998. Performance of growing calves fed on forest grass hay and wheat bhusa. Indian J. Anim. Res. 32(1): 23-29.

Steel, R.G.D. and J.A. Torrie. 1980. Principles and Procedures of Statistics. Mcgraw-Hill Book Co. Inc. New York.

Taiwo, A.A., A.D. Adejuyigbe, A.E. Adebowale, J.S. Oshotan and O.O. David. 2005. Performance and nutrient digestibility of weaned rabbits fed forage supplemented with concentrate. Nig. J. Anim. Prod. 31(1): 74-78.

Ukwah, B.N., I.M. Ezeonu, E.A. Eze and J.O. Uguru. 2014. Assessment of prebiotic roles of Musa paradisiaca (plantain) peels for controlling spread of Salmonella and other infectious disease agents by broilers. J. Biol. Chem. Res. 31(2): 901-911. 